\title{
Динаміка когнітивних функцій у хворих після ішемічного інсульту під впливом комплексу фізичної та медикаментозної реабілітації паретичної руки
}

\author{
В.А. Гриб, В.Р. Герасимчук, І.Ф. Ува-Агбонікхена, Н.П. Ткачук, О.О. Дорошенко, С.І. Геник
}

Івано-Франківський національний медичний університет, Івано-Франківськ, Україна

\begin{abstract}
Анотація. Мета: встановити ефективність комплексної фізичної та медикаментозної реабілітації паретичної руки щодо відновлення когнітивних функцій у хворих після ішемічного інсульту шляхом моніторингу параметрів когнітивних викликаних потенціалів (КВП). Об'єкт i методи дослідження. Обстежено 66 хворих (63,6\% - чоловіки, середній вік - 63 (54-72) роки) через 12-24 міс після ішемічного інсульту. Залежно від терапевтичної тактики пацієнтів рандомізували на три групи:у 1-й групі $(\mathrm{n}=21)$ пацієнти отримували комплекс фізичних вправ, у 2-й $(n=21)$ - загальні рухові вправи та комплекс вправ для паретичної кисті, у 3-й $(n=24)$ - додатково призначали холіну альфосцерат у дозі 400 мг 2 рази на добу. Лікування тривало 2 міс. Досліджували КВП Р300. Контрольну групу становили 20 практично здорових осіб відповідного віку. Пацієнтів обстежували до та через 2 міс після початку лікування. Застосовували статистичний аналіз результатів. Результати. Латентний період КВП Р300 у досліджуваних хворих подовжений у 1,3 раза порівняно з практично здоровими особами (р<0,001), а амплітуда хвилі Р300 - зменшена у 1,7 раза (p<0,001). Через 19-24 міс після інсульту амплітуда Р300 вірогідно відрізнялася від даних пацієнтів з постінсультним терміном 2-18 міс ( $p=0,008)$. Відмічено кореляційний зв'язок між когнітивними функціями, за даними Р300, та функціональною спроможністю кисті (тест дослідження функції руки (ARAT) та руки в цілому (шкала Фугл-Мейера): $r=0,77 ; \mathrm{p}<0,001 \mathrm{i} r=0,32$; p=0,029 відповідно. Через 2 міс лікування у пацієнтів 3-ї групи відмічали статистично значиму різницю латентного періоду (444 [415; 469] проти $474[440 ; 500]$ у П3О, p=0,022) та амплітуди P300 (6 [5; 6] проти $5[4 ; 6], p=0,024)$. У 2-й групі спостерігали вірогідне зростання амплітуди P300 ( $p=0,050)$, а латентний період мав тенденцію до зменшення ( $p=0,471$ проти $p=0,780)$. Висновки. У хворих із парезом руки в період 12-24 міс після інсульту відмічається зниження когнітивних функцій, за даними КВП Р300. Шкала АRАТ є більш дієвим інструментом, ніж шкала Фугл-Мейера, яка оцінює функцію руки в цілому, для визначення когнітивної функції пацієнтів із парезом руки у постінсультний період. Хворим, у яких не відбулося відновлення функціональної спроможності руки у перші місяці після інсульту, слід проводити комплекси фізичної та медикаментозної терапії у пізній віддалений період після інсульту.
\end{abstract}

Ключові слова: когнітивні порушення, постінсультний період, функція верхньої кінцівки, когнітивні викликані потенціали, реабілітація.

\section{Вступ}

У 40-70\% пацієнтів після інсульту, в тому числі легкого ступеня, можуть виникати когнітивні порушення [1]. Найвищий ризик їх розвитку відмічають у перші 6 міс, а через 12 міс, за даними науковців, кількість пацієнтів із постінсультними когнітивними розладами збільшується [2]. Результати дослідження з найдовшим терміном спостереження продемонстрували, що протягом 25 років після інсульту деменція розвивалася майже у половини пацієнтів [3]. Крім того, отримані нові докази того, що рухова дисфункція може також зумовлювати виникнення когнітивних порушень та їх прогресування. I навпаки, показано, що розумова активність впливає на відновлення функції руки [4, 5]. Відмічено, що когнітивний статус пов'язаний та залежний від дрібної моторики рук і у пацієнтів із хворобою Паркінсона [6].

Давно доведений зв'язок між когнітивними функціями і фізичними навантаженнями, тобто функціонування та пластичність головного мозку забезпечується аферентацією 3 периферії $[7,8]$. Чим більше сенсорної інформації, тим інтенсивніша реституційна здатність головного мозку [9], що забезпечує відновлення втрачених функцій. Стимуляція аферентних структур сприяє синаптичній перебудові. А сенсорна аферентація в першу чергу забезпечується рухом [10]. Отже, відмічається структуризація зворотного зв'язку із формуванням кола: рух (фізична реабілітація) - когнітивна активація - здатність до ефективного руху (кінцевий етап плану реабілітації).

Враховуючи обґрунтування цієї гіпотези, нами проведене дослідження за такою схемою: вплив фізичної реабілітації на найбільше проєкційне представництво в моторній корі проєкцію руки, індукований застосуванням холіну альфосцерату, попередника ацетилхоліну, який полегшує передачу імпульсів в холінергічних нейронах, покращуючи пластичність нейрональних мембран і функцію рецепторів.
Для оцінки когнітивних функцій пропонується вивчення параметрів когнітивних викликаних потенціалів (КВП) [11], що дозволяє аналізувати здатність розпізнати та запам'ятовувати стимул, а також тривало утримувати/концентрувати увагу. У генезі виникнення КВП Р300 при сенсорній стимуляції головного мозку задіяні такі структури, як скронево-тім'яна ділянка, моторна кора, верхня скронева звивина, інсула, префронтальна та дорзолатеральна кора, гіпокамп та амігдала, тому відповідь $\epsilon$ результатом їх сумарного функціонування [6]. Таким чином, виділяються та аналізуються ендогенні процеси в головному мозку, пов'язані з впізнанням стимулу, його обробкою та збереженням у пам'яті. Цей метод дозволяє визначити мінімальний ступінь когнітивної дисфункції та динаміку при проведенні терапії, яку не завжди можна виявити стандартними тестами.

Мета: встановити ефективність комплексної фізичної та медикаментозної реабілітації паретичної руки щодо відновлення когнітивних функцій у хворих після ішемічного інсульту шляхом моніторингу параметрів КВП.

\section{Об'єкт і методи дослідження}

Впродовж 2018-2020 рр. на базі кафедри неврології та нейрохірургії Івано-Франківського національного медичного університету після підписання інформованої згоди обстежено 66 хворих (63,6\% - чоловіки, середній вік 63 (54-72) роки) через 12-24 міс після перенесеного вперше у житті ішемічного інсульту в передньому басейні кровопостачання головного мозку. Інсульт локалізувався у правій півкулі у 36 (56,2\%) хворих.

Залежно від терапевтичної тактики, використовуючи програму випадкових чисел, хворих рандомізували на три групи. Всі пацієнти отримували вторинну профілактику інсульту. У 1-й групі $(n=21)$ пацієнтам призначали комплекс вправ для покращення загальної рухової функції, у 2-й $(n=21)$, крім загальних вправ, 
пацієнти отримували комплекс вправ для паретичної кисті, у 3-й $(n=24)$ - додатково до 2-компонентного комплексу вправ призначали холіну альфосцерат у дозі 400 мг 2 рази на добу. Лікування тривало 2 міс. Контрольну групу становили 20 практично здорових осіб (ПЗО) відповідного віку.

Пацієнтів обстежували до та через 2 міс після початку терапії. Стан функціональної спроможності руки досліджували:

- за доменом оцінки рухової та чутливої функції дистального та проксимального відділів верхньої кінцівки за шкалою Фугл-Мейера (Fugl-Meyer assessment - FMA) (0-66 балів) [12], умовно розділивши результати шкали на 3 градації: 0-22 бали - виражене порушення функції руки, 23-43 - порушення активності середнього ступеня тяжкості і 44-66 легкий ступінь дисфункції;

- за тестом дослідження функції руки (Action Research Arm Test - ARAT), який здатний детально оцінити функцію кисті та пальців (високий бал вказує на задовільну функцію кисті, оцінюється у 0-57 балів); у дослідженні результати тестування умовно розділені на 3 градації: 0-20 балів - виражене порушення функції кисті, 21-40 - порушення моторики середнього ступеня і 41-57 - легкий ступінь порушення функції кисті.

Використовували електрофізіологічний метод оцінки когнітивних функцій, метод слухових КВП, Р300 реєстрували на 16-канальному електроенцефалографі «DX-system» (Україна) за стандартною методикою [13] у науково-практичному центрі нейрофізіологічних досліджень кафедри неврології та нейрохірургії Івано-Франківського національного медичного університету (свідоцтво про технічну компетентність № 083/20).

Р300 - ендогенний потенціал, виникнення якого пов'язане з реакцією людини на стимул: при слуховій стимуляції у 1000 та 2000 Гц у випадковому порядку досліджуваний повинен зосередити увагу на диференціації тонів, натискаючи на кнопку на датчику при звуку 2000 Гц, який вважався значимим і займав 20\% всього часу подачі стимулів (всього 180 стимулів). Обробка отриманих результатів КВП Р300 складалася з двох незалежних процедур (оцінки поведінкових даних: кількість помилок (хибних натискань на кнопку) при фіксуванні та підрахунку значимих стимулів, що вимагало високого рівня концентрації уваги) та основних амплітудно-часових параметрів когнітивної відповіді (латентний період (ЛП) та амплітуда хвилі Р300 з центральних відведень справа/зліва - $\mathrm{C}_{3} / \mathrm{C}_{4}$ відповідно).

Статистичний аналіз результатів проводили за допомогою програм статистичної обробки даних «MS Excel» із використанням непараметричних методів. Для представлення міри центральної тенденції вибірки обрали медіану і міжквартильний розмах [Q25\%; Q75\%]. Кореляцію між параметрами оцінювали за коефіцієнтом рангової кореляції Спірмена. Ефективність лікування оцінювали за тестом Вілкоксона. Статистичну значимість визначали, як $\mathrm{p}<0,05$.

\section{Результати та їх обговорення}

Три групи досліджуваних хворих, рандомізованих за запропонованою схемою лікування, були зіставні за статтю, віком, тривалістю постінсультного періоду, ступенем функціонального дефіциту за шкалами FMA (для верхньої кінцівки) та ARAT ( $>>0,05)$ (табл. 1).

Таблиця 1 Характеристика хворих, рандомізованих за схемою лікування, Me [Q25\%; Q75\%]

\begin{tabular}{lccc}
\hline \multicolumn{1}{c}{ Показник } & $\begin{array}{c}\text { 1-ша група, } \\
\mathbf{n = 2 1}\end{array}$ & $\begin{array}{c}\text { 2-га група, } \\
\mathbf{n = 2 1}\end{array}$ & $\begin{array}{c}\text { 3-тя група, } \\
\mathbf{n = 2 4}\end{array}$ \\
\hline Стать, чоловіки/жінки & $12 / 9$ & $14 / 7$ & $16 / 8$ \\
\hline Вік, років & $65[61 ; 71]$ & $68[63 ; 73]$ & $62[58 ; 69]$ \\
\hline Тривалість постінсультного періоду, міс & $16[14 ; 19]$ & $15[14 ; 17]$ & $17[14 ; 20]$ \\
\hline Шкала МMSE, бали & $27[25 ; 29]$ & $27[24 ; 29]$ & $26[24 ; 28]$ \\
\hline Шкала FMA, бали & $37[30 ; 43]$ & $39[35 ; 43]$ & $38[32 ; 44]$ \\
\hline Шкала ARAT, бали & $29[22 ; 38]$ & $30[27 ; 35]$ & $28[20 ; 37]$ \\
\hline
\end{tabular}

MMSE (Mini-Mental State Examination) — коротка шкала оцінки психічного статусу.
Проаналізовано параметри КВП Р300. За характеристиками Р300 можна оцінити здатність людини до сприйняття, запам'ятовування та відтворення інформації, прийняття рішень та прогнозування ситуацій.

ЛП Р300 у обстежуваних пацієнтів був подовжений у 1,3 раза порівняно з групою П3О ( $<<0,001)$, а амплітуда хвилі Р300 зменшена у 1,7 раза $(\mathrm{p}<0,001)$ (табл. 2$)$.

Таблиця 2 Параметри P300 у хворих порівняно з П3О, Ме [Q25\%; Q75\%]

\begin{tabular}{lcc}
\hline \multicolumn{1}{c}{ Показник } & П30, $\mathbf{n = 2 0}$ & $\begin{array}{c}\text { Досліджувані хворі, } \\
\mathbf{n}=\mathbf{6 6}\end{array}$ \\
\hline ЛП, $\mathrm{MC}$ & $330[313 ; 344]$ & $479[445 ; 507]^{*}$ \\
\hline Амплітуда, мкВ & $10[9 ; 12]$ & $5[4 ; 5]^{*}$ \\
\hline
\end{tabular}

*(Татистично значима різниця із даними П30, $\mathrm{p}<0,05$.

Частота помилки (хибне натискання кнопки на датчику при появі незначимого звукового сигналу або відсутність натискання при появі значимого сигналу) у досліджуваних пацієнтів становила в середньому 40 із 180 можливих (Ме=22\% при значенні Ме=7\% у П3О; $\mathrm{p}<0,001)$.

Характеристика КВП Р300 залежно від статі, віку, тривалості постінсультного періоду, ступеня неспроможності руки за шкалами FMA та ARAT у досліджуваних представлена в табл. 3.

Таблиця 3 Загальна характеристика Р300 у пацієнтів із парезом руки після інсульту залежно від статі, віку, тривалості постінсультного періоду, ступеня неспроможності руки за шкалами FMA та ARAT, Me [Q25\%; Q75\%]

\begin{tabular}{|c|c|c|c|}
\hline \multicolumn{2}{|c|}{ Показник } & \multirow{2}{*}{$\begin{array}{c}\text { Латентність P300, } \\
\text { мс } \\
488[461 ; 507] \\
\end{array}$} & \multirow{2}{*}{$\begin{array}{c}\text { Амплітуда Р300, } \\
\text { мкВ }\end{array}$} \\
\hline Стать & Чоловіки n=42 & & \\
\hline & Жінки n=24 & $472[435 ; 515]$ & $5[4 ; 5]$ \\
\hline \multirow[t]{2}{*}{ Локалізація інсульту } & Справа & $473[433 ; 516]$ & $6[4 ; 7]$ \\
\hline & Зліва & $487[463 ; 511]^{*}$ & $5[4 ; 6]^{*}$ \\
\hline \multirow[t]{2}{*}{ Вік, років } & $54-64$ & $476[441 ; 510]$ & $5[4 ; 7]$ \\
\hline & $65-74$ & $484[452 ; 512]$ & $5[4 ; 6]$ \\
\hline \multirow{2}{*}{$\begin{array}{l}\text { Тривалість постінсультного } \\
\text { періоду, міс }\end{array}$} & $12-18$ & $480[436 ; 512]$ & $5[4 ; 6]$ \\
\hline & $19-24$ & $476[439 ; 511]$ & $4[3 ; 5]^{*}$ \\
\hline \multirow[t]{3}{*}{ Шкала FMA, бали } & $>44$ & $473[442 ; 500]$ & $7[6 ; 8]$ \\
\hline & $23-43$ & $482[448 ; 511]$ & $5[4 ; 7]$ \\
\hline & $<22$ & $488[461 ; 512]^{*}$ & $4[3 ; 5]^{*}$ \\
\hline \multirow[t]{3}{*}{ Шкала ARAT, бали } & $>41$ & $453[434 ; 458]$ & $6[5 ; 6]$ \\
\hline & $21-40$ & $476[444 ; 512]^{*}$ & $5[4 ; 6]^{*}$ \\
\hline & $<20$ & $489[469 ; 512]^{*, * *}$ & $4[3 ; 5]^{*}$ \\
\hline
\end{tabular}

*(татистично значима різниця з показником 1-ї категорії заданої характеристики, $\mathrm{p}<0,05$; **(татистично значима різниця з показником 2-ї категорії заданої характеристики, $\mathrm{p}<0,05$.

Не виявлено суттєвої різниці параметрів Р300 у гендерному відношенні $(p=0,533)$, відмічали продовження ПЛ при лівопівкульній локалізації інсульту $(\mathrm{p}=0,011)$ та відсутність такої різниці у хворих із різним терміном після інсульту $(p=0,087)$. Автори наукового спостереження за станом хворих впродовж 1 року після інсульту зазначили відсутність міжпівкульної асиметрії щодо ЛП Р300 через 3 та 6 міс, який значимо подовжувався при лівопівкульному інсульті на початку дослідження [14]. У нашому дослідженні амплітуда Р300, показник якої характеризує рівень уваги, зіставлений із завданням (робоча пам'ять), вірогідно відрізнявся залежно від часу, що минув після інсульту $(p=0,021)$.

Відомо, що з кожним роком життя ЛП піку Р300 збільшується на 1,25 мс [15], хоча нами не відмічено міжвікової різниці показника ЛП $(p=0,161)$ : можливо, показники ЛП мали би вірогідну різницю при порівнянні досліджуваної когорти із віковою категорією старечого віку. Девіація результатів амплітуди Р300 залежно від вивчених характеристик мала такий самий характер, як і дані ЛП, хоча була одна відмінність: у групі пацієнтів, у яких минуло 19-24 міс після інсульту, амплітуда хвилі Р300 статистично значимо відрізнялася від даних пацієнтів із постінсультним терміном 
2-18 міс ( $p=0,008)$. Тобто рівень уваги з плином часу після інсульту знижувався, що є однією зі складових когнітивних функцій.

Спостерігали наростання когнітивної дисфункції у досліджуваних хворих залежно від ступеня неспроможності дистального та проксимального відділу верхньої кінцівки за шкалою FMA, а також тільки кисті - за шкалою АRAT. Встановлено кореляційний зв'язок між показниками цих шкал $(r=0,37 ; p=0,032)$, латентність Р300 вірогідно відрізнялася серед пацієнтів залежно від ступеня неспроможності кисті, визначеної за шкалою ARAT, і була найдовшою при вираженому ступені порівняно $з$ показником при легкому та помірному ступенях дисфункції кисті ( $p=0,009$ та $\mathrm{p}=0,041$ відповідно). За шкалою FMA відмічено вірогідне подовження ЛП тільки при вираженому ступені, на відміну від даних ЛП Р300 при легкій дисфункції всієї верхньої кінцівки ( в той самий час відмічали тенденцію до відмінності між показниками ЛП при помірному та тяжкому ступені моторного дефіциту руки, але різниця не досягла вірогідного значення $(p=0,088)$. Оцінивши взаємозалежність когнітивної функції, за даними Р300, хворих після інсульту та функціональну спроможність кисті (шкала ARAT) та руки в цілому (шкала FMA), отримано значимий кореляційний зв'язок між даними: $r=0,77, p<0,001$ та $r=0,32, p=0,029$ відповідно; сильний зв'язок відмічено у першому випадку.

Отримані дані дають підставу вважати шкалу ARAT більш чутливою щодо оцінки когнітивних функцій у хворих із паретичною рукою у постінсультний період, адже спритність руки та дрібну моторику вважають одними з найважливіших маркерів рівня та збереження когнітивних функцій [16].

Використовуючи різні методики лікування хворих з метою довести ефективність комбінованого застосування загальних фізичних вправ, специфічної фізичної терапії паретичної кисті та медикаментозної терапії холіну альфосцератом, отримано такі результати (табл. 4).

Таблиця 4 Динаміка показників КВП Р300 залежно від схеми лікування

\begin{tabular}{lcccc}
\hline \multicolumn{1}{c}{ Показник } & Період & $\begin{array}{c}\text { 1-ша група, } \\
\mathbf{n}=\mathbf{2 1}\end{array}$ & $\begin{array}{c}\text { 2-га група, } \\
\mathbf{n = 2 1}\end{array}$ & $\begin{array}{c}\text { 3-тя група, } \\
\mathbf{n}=\mathbf{2 4}\end{array}$ \\
\hline \multirow{2}{*}{ Латентність P300, мС } & До лікування & $481[450 ; 511]$ & $483[444 ; 520]$ & $474[440 ; 500]$ \\
\cline { 2 - 5 } & Через 2 міс & $478[446 ; 510]$ & $470[424 ; 495]$ & $444[415 ; 469]^{*}$ \\
\hline p & & 0,780 & 0,471 & 0,022 \\
\hline \multirow{2}{*}{$\begin{array}{l}\text { Амплітуда Р300, } \\
\text { мкB }\end{array}$} & До лікування & $5[4 ; 6]$ & $5[3 ; 5]$ & $5[4 ; 6]$ \\
\cline { 2 - 5 } & Через 2 міс & $6[4 ; 7]$ & $5[4 ; 6]^{*}$ & $6[5 ; 6]^{*}$ \\
\hline p & & 0,191 & 0,050 & 0,024 \\
\hline
\end{tabular}

*(татистично значима різниця із даними 1-їгрупи; $p<0,05$.

Через 2 міс лікування у пацієнтів 3-ї групи, які отримували повний терапевтичний комплекс, відмічали статистично значиму різницю обох параметрів КВП Р300: ЛП, що характеризує час, який потрібен для прийняття рішення, виходячи з поставленого завдання, та амплітуди Р300, тобто зростав рівень уваги. У пацієнтів, в яких крім загального комплексу вправ пропонували виконання підібраного комплексу реабілітації кисті, також відмічали зростання амплітуди Р300 ( $p=0,050)$, а ЛП мав тенденцію до зменшення, хоча вірогідної різниці не визначали. Вважаємо, що хворим, у яких не відбулося відновлення функціональної спроможності руки у перші місяці після інсульту, слід проводити комплекси реабілітаційних втручань, незважаючи на тривалий час, який минув після інсульту, із застосуванням препаратів, що мають здатність активувати нейропластичність, оскільки, як видно з результатів наукової роботи, намітилася хороша тенденція щодо відновлення когнітивного потенціалу паці$\epsilon$ нтів із перспективою подальшої позитивної динаміки. Мабуть, недостатньо одного курсу терапії, хоча це слід встановити тривалим спостереженням і тривалим лікуванням таких пацієнтів.

Кількісна оцінка нейропластичності в ураженій руховій корі в обох півкулях головного мозку після інсульту продемонструвала «період посиленої синаптичної пластичності», хоча вона була найефективнішою через 2 тиж після події. Враховуючи здатність головного мозку до нейропластичності, B. Hordacre та співавтори (2021) стверджують, що реабілітація і у пізніші терміни може бути ще більш важливою через затримку на початку терапевтичного процесу або неефективність ранньої фізичної терапії [17]. Це впливатиме на поліпшення когнітивних функцій і, в свою чергу, на зростання мотиваційних можливостей пацієнта до відновлення та покращення пластичності нейронів, а в цілому 一 до підвищення якості життя.

\section{Висновки}

У хворих із парезом руки в період 12-24 міс після інсульту відмічено зниження когнітивних функцій, за даними КВП P300: ЛП Р300 подовжений у 1,3 раза порівняно з групою П3О ( $p<0,001)$, амплітуда хвилі Р300 - зменшена у 1,7 раза $(p<0,001)$.

Шкала ARAT $\epsilon$ більш дієвим інструментом, ніж шкала FMA, яка оцінює функцію руки в цілому, для визначення когнітивної функції пацієнтів із парезом руки у постінсультний період, враховуючи встановлений сильний кореляційний зв'язок $(r=0,77 ; p<0,001)$ у взаємозалежності когнітивної функції, за даними КВП Р300 хворих, та ступенем функціональної спроможність кисті.

Хворим, у яких не відбулося відновлення функціональної спроможності руки у перші місяці після інсульту, слід проводити комплекси фізичної та медикаментозної терапії у пізній віддалений період після інсульту, що впливатиме на поліпшення когнітивних функцій і, в свою чергу, на зростання мотиваційних можливостей пацієнта до відновлення та покращення пластичності нейронів, а в цілому - до покращення якості життя.

\section{Перспективи подальших досліджень}

Планується тривале спостереження хворих після інсульту щодо стану когнітивних функцій у взаємозв'язку із рівнем функціональної спроможності верхньої кінцівки при проведенні їм періодичних курсів фізичної та медикаментозної терапії.

\section{Фінансування}

Не отримано.

\section{Персональний внесок кожного}

\section{3 авторів у підготовку статті}

В.А. Гриб - ідея дослідження, формування мети; В.Р. Герасимчук - оформлення дизайну дослідження; І.Ф. Ува-Агбонікхена - пошук літературних джерел за темою, набір хворих, клініко-неврологічне дослідження, формування таблиць результатів дослідження; Н.П. Ткачук — проведення КВП Р300; О.О. Дорошенко - методики статистичного аналізу; С.І. Геник - огляд літератури/вступ.

Конфлікт інтересів: відсутній.

Conflict of interests: the authors declare no conflict of interests.

\section{Список використаних джерел/References:}

1. Pendlebury S.T., Rothwell P.M. (2019) Incidence and prevalence of dementia associated with transient ischaemic attack and stroke: analysis of the population-based Oxford Vascular Study. Lancet Neurol., 18(3): 248-258. D0I: 10.1016/S1474-4422(18)30442-3

2. Pendlebury S.T., Chen P.J., Bull L. et al. (2015) Methodological factors in determining rates of dementia in transient ischemic attack and stroke: (I) impact of baseline selection bias. Stroke, 46: 641-646. DOI: org/10.1161/STROKEAHA.114.008043

3. Kishimoto H., Ohara T., Hata J. (2016) The longterm association between physical activity and risk of dementia in the community: the Hisayama Study. Eur. J. Epidemiol., 31(3): 267-274. DOl: 10.1007/ s10654-016-0125-y

4. Corbetta D., Imeri F., Gattic R. (2015) Rehabilitation that incorporates virtual reality is more effective than standard rehabilitation for improving walking speed, balance and mobility after stroke: a systematic review. J. Phisiother., 61(3): 117-124. D0I: 10.1016/j.jphys. 2015.05.017

5. Shi Y.X., Tian J.H., Yang K.H., Zhao Y. (2011) Modified Constraint-Induced Movement Therapy Versus Traditional Rehabilitation in Patients With Upper-Extremity Dysfunction After Stroke: A Systemic Review and Meta-Analysis. Arch. Phys. Med. Rehab., 92(6): 972-982. D0l: 10.1016/j.apmr.2010.12.036

6. Tan S., Hong C.T., Chen J.-H., Chan L. (2020) Hand Fine Motor Skill Disability Correlates with Cognition in Patients with Moderate-to-Advanced Parkinson's Disease. Brain Sci., 10(6): 337. DOl:10.3390/brainsci10060337

7. Baker L.D., Frank L.L., Foster-Schubert K. et al. (2010) Effects of aerobic exercise on mild cognitive impairment: a controlled trial. Arch. Neurol., 67(1):71-79. D01: 10.1001/archneurol.2009.307 
8. Blondell S.J., Hammersley-Mather R., Veerman J.L. (2014) Does physical activity prevent cognitive decline and dementia? A systematic review and meta-analysis of longitudinal studies. BMC Public Health, 14(1): $510 \mathrm{p}$.

9. Morgan G.S., Gallacher J., Bayer A. et al. (2012) Physical activity in middle-age and dementia in later life: findings from a prospective cohort of men in caerphilly, South Wales and a metaanalysis. J. Alzheimer's Dis., 31(3): 569-580. D0I: 10.3233/JAD-2012-112171

10. Guire C.B., Ibrahim N.A., Adam M.B., Said S.M. (2017) Impact of physical activity on cognitive decline, dementia and its subtypes: meta-analysis of prospective studies. Biomed. Res. Int. DOI: $10.1155 / 2017 / 9016924$

11. Vasilyeva N.Yu., Zharinov 0.J., Stolyarov G.S. et al. (2013) Usage of the cerebral evoked potentials for study of the cognitive functions. UMJ, 4(96): 171-175. (In Rus.).

12. Fugl-Meyer A.R., Jääskö L., Leyman I. et al. (1975) The post-stroke hemiplegic patient. 1. A method for evaluation of physical performance. Scand. J. Rehabil. Med., 7(1): 13-31.

13. Duncan C.C., Barry R.J., Connolly J.F., Fischer C. (2009) Event-related potentials in clinical research: Guidelines for eliciting, recording, and quantifying mismatch negativity, P300, and N400. Clin. Neurophisiol., 120(11): 1883-1908. D0l: 10.1016/j.clinph.2009.07.045

14. Dejanovic M., Ivetic V., Nestorovic V., Eric M. (2015) The role of P300 event-related potentials in the cognitive recovery after the stroke. Acta Neurol. Belg., 115: 589-595. D0l: 10.1007/ s13760-015-0428-X

15. Faraci F.M. (2011) Protecting against vascular disease in brain. Am. J. Physiol. Heart. Circ Physiol., 300(5): 1566-1582. D0l: 10.1152/ ajpheart.01310.2010

16. Clouston S.A.P., Brewster P., Kuh D. et al. (2013) The dynamic relationship between physical function and cognition in longitudinal aging cohorts. Epidemiol. Rev., 35: 33-50. DOI: 10.1093/epirev/mxs004

17. Hordacre B., Austin D., Brown K.E. et al. (2021) Evidence for a Window of Enhanced Plasticity in the Human Motor Cortex Following Ischemic Stroke. Neurorehabil. Neural. Repair., 10(6): 337. D0l: $10.3390 /$ brainsci10060337

\section{Dynamics of cognitive functions in post-stroke patients under the influence of physical and pharmacological rehabilitation complex of the paretic arm}

\section{V.A. Gryb, V.R. Gerasymchuk, I.F. Uwa-Agbonikhena,} N.P. Tkachuk, O.O. Doroshenko, S.I. Henyk

Ivano-Frankivsk National Medical University, Ivano-Frankivsk, Ukraine
Abstract. The aim was to determine the efficacy of complex physical and pharmacological rehabilitation of the paretic arm in recovery of cognitive functions in patients after ischemic stroke with the use of cognitive evoked potentials parameters (CEP) monitoring. Object and methods. 66 patients $(63.6 \%$ males, the mean age 63 (54-72) years) in the period of 12-24 months after ischemic stroke were examined. Depending on the therapeutic tactics, patients were randomized into 3 groups: patients of group $1(n=21)$ performed the exercise complex for general muscle function improvement, group $2(n=21)$ also performed the exercise complex for paretic hand function improvement, group $3(n=24)$ were additionally prescribed choline alfoscerate $400 \mathrm{mg}$ twice a day. The control group consisted of 20 apparently healthy individuals of the appropriate age. The treatment lasted 2 months. The CEP P300 was investigated. Patients were examined before and after 2 months of treatment. Statistical analysis of the results was used. Results. The latent period of the CEP P300 was 1.3 times prolonged compared to the apparently healthy individuals ( $p<0.001)$, and the P300 wave amplitude was decreased by 1.7 times $(p<0.001)$. In the period of $19-24$ months after stroke, the P300 amplitude significantly differed from the indices of patients in the period of $2-18$ months $(p=0.008)$. The correlation between cognitive functions according to P300 data, hand function (ARAT scale) and the entire upper extremity function (FuglMeyer scale) was observed $(r=0.77 ; p<0.001$ and $r=0.32 ; p=0.029$, respectively). After 2 months of treatment, patients in group 3 showed a statistically significant difference between latent period $(444[415 ; 469]$ vs. $474[440 ; 500]$ in apparently healthy individuals, $p=0.022$ ) and amplitude P300 [6 [5;6] vs. $5[4 ; 6], p=0.024)$. In group 2 , a significant increase in the amplitude of P300 was observed $(p=0.050)$, and latent period tended to decrease $(p=0.471$ vs. $p=0.780$ ). Conclusions. Cognitive impairment according to the CEP P300 data is observed patients with arm paresis in the period of 12-24 months after stroke. The ARAT scale is a more effective tool than the Fugl-Meyer scale, which assesses arm function in general, in determination of the cognitive function of patients with arm paresis in the post-stroke period. Patients who have not recovered the arm functional ability within the first months after stroke should receive physical and pharmacological therapy in the residual stroke period.

Key words: cognitive impairment, post-stroke period, upper extremity function, cognitive evoked potentials, rehabilitation.

\section{Information about the authors:}

Gryb Viktoriia A. - MD, PhD, DSci, professor, head of Neurology and Neurosurgery Department of the Ivano-Frankivsk National Medical University, Ivano-Frankivsk, Ukraine. ORCID ID: 00000001-6111-7921

Gerasymchuk Viktoriia R. — MD, PhD, associate professor of Neurology and Neurosurgery Department of the Ivano-Frankivsk National Medical University, Ivano-Frankivsk, Ukraine. ORCID ID: 0000-0001-8481-8253

Uwa-Agbonikhena Iriah F. — MD, PhD candidate, Neurology and Neurosurgery Department of the Ivano-Frankivsk National Medical University, Ivano-Frankivsk, Ukraine. ORCID ID: 0000-00022914-1523

Tkachuk Nataliia P. - MD, PhD, assistant of Neurology and Neurosurgery Department of the Ivano-Frankivsk National Medical University, Ivano-Frankivsk, Ukraine. ORCID ID: 0000-00034477-3059

Doroshenko Olexandr Olexandrovich — MD, PhD, associate professor of Neurology and Neurosurgery Department of the Ivano-Frankivsk National Medical University, Ivano-Frankivsk, Ukraine. ORCID ID: 0000-0002-7982-2108

Henyk Sofiia I. - MD, PhD, associate professor, Neurology and Neurosurgery Department of the IvanoFrankivsk National Medical University, Ivano-Frankivsk, Ukraine. ORCID ID: 0000-0003-4068-186X

Address for correspondence:

Viktoriia Gryb

76018, Ivano-Frankivsk, Halytska str., 2

E-mail:gmne@ukr.net 